\title{
Child Welfare in Ghana: The Past, Present and Future
}

\section{Dr. Kwabena Frimpong-Manso}

University of Ghana

kfmanso@ug.edu.gh

Doi:10.5901/jesr.2014.v4n6p411

\section{Abstract}

Drawing on a review of the literature, this article presents an examination of child welfare policies and practices in Ghana. It traces the historical development of child welfare, from the colonial era of the Gold Coast to the present day Ghana, taking into account the social, political and economic context and the impact of globalisation. The major forms of substitute parental care, the reasons why children and young people require care as well as laws and policies within different periods are highlighted. The article ends with a description of the future prospect and challenges of the child welfare system.

Keywords: Child welfare, Ghana, Children, Deinstitutionalisation, Alternative Care

\section{Introduction}

Children have always occupied a special position in Ghana because they are considered the custodians of the future. In the pre-colonial days, children were the most precious of one's possessions (Gyekye, 1996). Hence, the welfare and protection of children were an important communal undertaking and one's status in society was judged by his or her assumed responsibilities for children of relatives. However, provision for children in Ghana has changed over the years. What is evident from the literature is that the nature of the current child welfare system in Ghana has been shaped by events that occurred in the past. This article, therefore offers an overview of child welfare in Ghana. It traces the historical development of child welfare, from the colonial era of the Gold Coast to the present day Ghana, taking into account the social, political and economic context and the impact of globalisation. The major forms of substitute parental care, the reasons why children and young people require care, as well as laws and policies within different periods are highlighted. The article ends with a description of the current reform of the child welfare system and the potential challenges to it.

\section{The Past: Child Welfare Pre-Independence Era (-1957)}

Although no child welfare system existed per in the pre-colonial Gold Coast, it was customary for the extended family, through kinship foster care and other community networks, to provide care and protection for children whose parents were unable to do so (Goody, 1966). Cultural practices including Zuguliem ${ }^{1}$ made it possible for children from dysfunctional or poor families to be fostered to kinsmen to receive proper upbringing or an education or learn a trade (Oppong, 1973). Orphans were also cared for by childless members of the clan. Community members were also committed to the welfare of children because they believed it "took a village to raise a child". Therefore, when children did not have biological families to care for them, the community felt indebted to provide guardianship (Ansah-Koi, 2006). The advantage of this system for children was that they always had more than two adults whom they could depend on and who were concerned about their welfare.

The kinship foster care was based on the values of reciprocity, altruism and the fear of reprisal from dead kinsmen (Ansah-Koi, 2006). Kaye (1962: 37) notes that the extended family took care of orphans because they feared:

"The spirits of the dead parent, particularly that of the mother, is watching to see how the child is treated, and will reward with misfortune and calamities those foster-parents who neglect their charges".

The close pattern of settlements and living arrangements made it easier for such a welfare system to operate (Nukunya, 2003). Most extended families, consisting of several generations, resided in the compound houses in small

1 It is the practice among the Dagomba's where drummers take their sisters' and daughters children to rear and train them in their profession. Goody (1973) found similar practices by the Gonja 
rural communities which made it easier for family members to provide substitute parental care. Anecdotal evidence suggests that among the Akan descent groups, certain women had designated responsibilities of taking care of children, orphans and the elderly. These women were then taken care of by the other family members and they could only get married if their husbands agreed to reside within the wife's family house.

However, the traditional society did not remain static. As a result of social change and economic pressure, the kinship foster care system gradually lost some of its capacity to respond to the requirements of children needing alternative parental care. The advent of colonial rule saw the beginning of modern cities and industrialisation in Ghana. People migrated to the cities in search of jobs in the construction sites and industries (Fiaw00, 1959; Little, 1960). The rural-urban drift according to Schildkrout (1973) weakened the extended family system. Men who migrated to the urban centres often did so without their wives and children, contributing to a breakdown of families (Manful and Badu-Nyarko, 2011). The migrants also had little in common, resulting in limited social cohesion, neighbourliness and sense of responsibility towards dependent children. The economic depression before World War II, also led to several fostered children being cast from their homes and forced to fend for themselves (Agyeman-Duah, 2008).

In addition to these economic and social changes, children's rights as it is known today was largely absent during the pre-colonial era. Children were considered properties of their parents and the lineage rather than individuals with their rights and entitlements (Ampofo et al., 2007). The understanding of children as properties reflected in the lack of consideration given to their rights and protection in certain cultural practices which included pawning of children and ostracizing of severely disabled children (Mends, 1992).

European missionaries were the first group outside the extended family to provide assistance for vulnerable children (Hill, 1962). Informal, missionary activity in caring for abandoned, orphaned and infirm children was of particular importance especially in instances where cultural inhibitions forbade certain categories of children from being raised in the traditional family or the urban centres where the traditional foster care was non-existent. The Presbyterian and Methodist churches, for instance, established schools for disabled children (Anson-Yevu, 1988). Infant welfare centres operated by Missionaries also helped to reduce infant mortality, from 360/1000 live births in 1915 to 95/1000 live births by 1931 (Asrifi, 2009).

The British provision for child welfare during the early parts of the colonial era was rather limited. It was British policy not to encourage services that the colonies could not fund internally (Hill, 1962). Like many other colonies in Africa, the colonial administration's response to providing care for children was basically to import what was being used in the United Kingdom (Asamoah, 1997). With little experimentation or determination of community preferences, child welfare provision in the colonial period focused on residential care. The Children Care and Reformation Ordinance of 1928, gave the Juvenile courts the authority to put juvenile delinquents orphans, neglected or otherwise ill-treated children under the age of fifteen in a reformatory (Craven, 1935). The institutions were concentrated in the urban areas where the colonial power was concentrated and used to prevent any threats to law and order from these children (Apt and Blavo, 1997).

In 1940, the Colonial Development and Welfare Act made funds available for welfare services in the British colonies. A Department of Social Welfare (DSW) was subsequently created and child welfare began to receive more systematic attention. The DSW assumed responsibility for the reformatory and industrial schools for juvenile delinquents with the aim of inculcating in children the need to lead an honest and industrious life (Apt, Blavo and Wilson, 1998). In 1949 the Child Care Society, a charity organization, established the first children's home (Osu Children's Home) to take care of orphans and abandoned children (Payne and White, 1979).

The child welfare practice introduced by these foreign groups were, however detrimental to the emergence of welfare practices suitable to the needs of the indigenous people. The British system was incompatible with the structure, values and concepts of the traditional childcare system (Asamoah and Nortey, 1987; Apt and Blavo, 1997). According to Casey (2011) the investigative and court ordered intrusions of this system did not reflect the family-focused and consensus-based approaches to decision-making used in the traditional childcare system. The new approach failed to engage the extended family system and degraded its role in the care of dependent children.

\subsection{Post independence: Child welfare during the austerity years (1957-1991)}

Ghana embarked on massive industrial and infrastructural development in the urban areas from the money bequeathed the country by the British. The government considered this development agenda the best way for addressing poverty and deprivation and making the country self-reliant and the period witnessed some economic growth (Aryeetey and Goldstein, 2000). A consequence of this economic policy was an explosion of urban migration of people looking for work in the new industries that were mainly located in the regional capitals. The good economic conditions provided the funds 
for child sensitive policies such as the Education Act of 1961 which made primary education free and improved school enrollment.

The period of relative economic prosperity, however, did not last long. From later parts of the 1960s to the mid 1980s a combination of factors took the country into economic austerity. The prices of the country's major exports fell sharply, the population increased rapidly at $3 \%$ per annum whilst four successive corrupt military dictators from 19661979 just concerned themselves with amassing personal wealth (Gocking, 2005). To curb the economic downturn, Ghana implemented Structural Adjustment Programs in the early 1980s (SAPs) which resulted in the removal of farm subsidies $^{2}$, retrenchment of public service workers and cuts in social spending especially in health and education (Adésínà, 2009). Though the SAP ensured sustained economic recovery, it increased poverty for large sections of the populace, reaching 52\% of the population in 1991 (Konings, 2002). Oppong (1987) has argued that women and children were most affected by the collapse of the national economy.

Without a clear-cut policy direction after independence, subsequent governments adopted the child welfare provision employed during the colonial period (Laird, 2002). Residential care continued as the main form of social provision for children needing formal alternative care. The state assumed responsibility for the Osu Children's Home through the Criminal Offenses Act 1960 (Act 29) (Akpalu, 2007). By 1998, the government had built two state children's homes and entered into partnership with six private orphanages taking care of over 350 children (Apt, Blavo and Wilson, 1998).

Aside the growing poverty, certain practices within the matrilineal and patri-lineal kin groups made parents (especially fathers) shun their responsibilities to their children, including those in state care. Among the matrilineal Akans, for instance, ntamboa allowed a child's maternal uncle to end a father's right to his children by paying him compensation (Allman, 1997). Even within patrilineal Krobo's, fathers of children born out of wedlock or those referred to as yobime (women's children), were denied their paternity rights (Atobrah, 2004). Research conducted by the Department of Social Welfare and Community Development (DSWCD) in 1955 indicated that:

"The most frequent caller at the local offices of the Department of Social Welfare has been for a long time the woman who is trying to get money from the father of her children in order to maintain them" (p. 23).

These cultural practices undermined father's responsibility to their children and increased mothers stake in ensuring their children's survival (Bukh, 1979). A seminal study on residential care by Apt (1974) found that the majority of children in state care were those whose mothers: (1) migrated to neighbouring countries in search of greener pastures, (2) died at childbirth, (3) mentally ill or destitute. The study indicated that the biggest problem for DSWCD was how to get relatives of the children in care interested and responsible for children's welfare (Apt, 1974: 84) According to Apt this was an indication of the importance of mothers in the care of Ghanaian children and made true the popular Akan adage "when the mother dies the child has no family". This theme was also highlighted in Van der Geest (2004) anthropological interpretation of the plight of orphans in Ghana.

In terms of child welfare legislation the government also passed the Children's Maintenance Act (Act 297) in 1965 to deal with paternity and maintenance issues. The Act established that fathers and their successors were legally responsible for providing fixed child support. However, social welfare workers found it tough enforcing child support because of the difficulty in accessing incomes of informal sector workers (Laird, 2011). The Maintenance of Children Decree (1977) was therefore passed to replace Act 297. The new law established family tribunals to adjudicate on child maintenance and paternity cases and also made both parents legally liable for the maintenance of their child(ren). Additionally, it removed the fixed amount of $\mathbb{\mathbb { } 1 0 . 0 0}$ per month and made child maintenance payments assessable on the earnings of the parent responsible for the maintenance of the child. Other legislation that passed within this period which affected children included the 1962 Adoption Act (Act 104) to regulate the adoption of children as well as Registration of Births and Deaths Act 1965 (Act 301) which made birth registration compulsory.

The Ministry of Foreign Affairs based on the recommendations of the International Year of the Child, set-up the Ghana National Commission on Children (GNCC) through the AFRCD 66 statute in 1979. It became the first organisation in Ghana established to protect the welfare and development of children, coordinate agencies that provide services for children (e.g. crèches and daycare centres) and advise the government on child legislation. However, budgetary allocations for child oriented services and agencies was very limited making the GNCC largely ineffective in carrying out its core functions. This led to a growth of local and international Non Governmental Organisations (NGOs) as well as multilateral donor organisations in the provision of child welfare services.

${ }^{2}$ A sector that employed the bulk of the country's working population 


\section{The Present: Child Welfare After the Restoration of Democracy (1990-2005)}

The reasons why children are taken into state care in Ghana have been changing but the main reasons include poverty, harmful traditional practices, and recently HIVIAIDS (UNDP, 2004). Poverty is the major factor that affects parents and extended families' ability to care for children illustrated by the over 10000 child maintenance cases handled by the DSW yearly (Laird, 2002). Frequent media reports of child abandonment, child labour, neglect, and sale of children indicate the difficulties that some parents go through in providing for the maintenance and care of children (Windborne, 2006).

Although Ghana has ratified and enacted various legislation, several childrens' rights are abused through harmful traditional practices such as Trokosi ${ }^{3}$, early marriages before 18 years (24\% in 2006), female genital mutilation/cutting (4\% in 2006), necessitating their need for care and protection from the state (Ghana Statistical Service, 2008). Though laws have been enacted to illegalise these practices, they are so deeply ingrained in the traditional belief system that it has been very difficult to curtail them (Sossou and Yogtiba 2009; Murove et al., 2010). Another factor that has contributed to children requiring out-of-home care is HIVIAIDs pandemic. Though still low compared to other African states like South Africa and Uganda, the number of children orphaned by the disease has been rising and was over 150,000 in 2009 (United Nations Children's Fund, 2009). The rising number of HIV and AIDS orphans has further stretched the traditional welfare system and some children have fallen through this informal safety net of support. Some investigators (Crenstil, 2009) have stated that HIV and AIDS orphans have a heightened vulnerability to abuse and poor livelihoods because of the stigma attached to the disease.

\section{Legislation}

From the early parts of 1990s to the mid-2000s little political strife and democratic governance ensured that Ghana made significant progress in strengthening its child welfare system. The return to constitutional rule was particularly influential in transforming legislation and institutions relating to child and family welfare. This subsequently affected the nature and form of child welfare provision and even the types of children coming into out-of-home care. Ghana became the first country in the world to ratify the United Nations Convention of the Rights of the Child (hereafter the UNCRC) in 1990. In addition, the 1992 Constitution mandated Parliament to enact child related legislation guided by the tenets of international human rights instruments such as the UNCRC. Hence a five year national plan of action (1993-1997) dubbed "The Child Cannot Wait" was implemented to reflect the provisions in the UNCRC to the actual circumstances of children in Ghana.

However, as of 1995 the "existing law (maintenance decree) did not reflect international standards or take into account the country's ability to secure the resources for implementation" (Khemchyan et al., 2008; 80). The Maintenance Decree failed to ensure the well-being of children because it was largely silent over protection issues. Except for a few cases that made the headlines, many children who were cruelly and violently treated by their caregivers failed to receive any redress in the courts. Consequently, the GNCC established an advisory committee in 1995 to reform the country's child laws. The end product of the committee's work was the 1998 Children's Act (Act 560), an imitation of the 1989 Children's Act of England and Wales (Laird, 2002). According to Laird (2002), the United Nations Children's Fund (UNICEF) and other multi-lateral donor agencies were also influential in calling for the introduction of a rights based approach to the care and protection of children. Laird suggests that these donor agencies had a lot of influence in setting the child welfare agenda because the funding they provided for child welfare programs often rivaled or exceeded what the government provided.

With its enactment, the Children's Act 1998 became the main law governing child welfare in Ghana. The passage of the Children's Act brought about several significant changes to child welfare and protection in Ghana. Firstly, it brought into existence laws to regulate childcare facilities that hitherto was absent and paved the way for the passage of other child welfare legislation such as the Child Rights Regulations 2002 (LI 1705) the Juvenile Justice Act 2003 (Act 653), and Human Trafficking Act 2005 (Act 694). Secondly, district assemblies were given the responsibility to liaise with other government for ensuring the protection and welfare of children within their jurisdiction.

\footnotetext{
${ }_{3}^{3}$ Trokosi is a traditional fetish practice in Ghana in where young girls, who are virgins, are given to the priests and priestesses of fetish shrines as slaves to appease for sins and crimes committed by their relatives against the deities. The young girls are sexually abused by the fetish priests.
} 


\subsection{Approaches to child welfare}

Due to the renewed interest in protecting the rights of children in the past two decades, the Ministry of Women and Children's Affairs established in 2001 to take the lead and coordinate gender and child receptive development issues through the formulation and implementation of child friendly policies and increased child participation. It also aims to create awareness among both adults and children on the rights of children, which are provided for by the CRC and the national laws relating to children. The Department of Social Welfare (under the Ministry of Employment and Social Welfare) has the primary responsibility for implementing child welfare services (Apt and Akuffo-Amoabeng, 2007). Social workers deliver services in the districts in the country. However, due to the lack of manpower, some districts, especially those in the rural areas, have no social workers.

NGOs play a major role in the provision of child welfare services. They work to address child protection issues, and several NGOs have formed the Ghana Coalition on the Rights of the Child. An example of the child protection work being undertaken by NGOS are the child protection teams that are sponsored by UNICEF to monitor children's rights and promoting positive child care practices especially in the rural area (Apusigah, 2007). Traditional leaders (Chiefs and Queen Mothers) play an important role in local governance, especially within the rural communities. In 2003 the Manya Krobo Queen Mothers ${ }^{4}$ Association in the Eastern region started an innovative foster care system that promotes community based care for orphans and vulnerable children. Using the principles of the traditional welfare system (e.g., reciprocity and responsibility), the Queen Mothers identify and take in up to six dependent children and raise them as part of their own family. The Queen Mothers receive some support from organisations such as the Ghana Aids Commission, District Assembly and the Ministry of Health. In 2012 there were 371 Queen Mothers caring for 1,035 children (Bortey-Doku Aryeetey, 2012). The advantage of this care arrangement, according to Lund and Agyei-Mensah (2008), is that helps remove the stigma that AIDs orphans within their communities and helps in their integration into their communities.

\subsection{Formal and informal provision}

Although not used extensively as in previous years ${ }^{5}$, alternative parental care for children is still largely provided through the traditional kinship foster care system (UNDP, 2007). However, unlike kinship fostering in western countries, decisions concerning the placement of children in this foster system are made informally by family members and social welfare workers do not monitor the circumstances of children in these placements. Foster parents are also not entitled to benefits from the state or assistance from the child's natural parents since it is considered an extended family obligation (Fiawoo, 1978). Yet, with the rising costs of education and economic hardships, many people began to consider foster children as an economic burden (Imoh Twum-Danso, 2012). Recent research studies (Apt, 2005; Tetteh, 2010; Kuyini et al., 2009) show that some foster children are in domestic servitude, physically abused or being denied education. In addition, a study of street children also found that over $50 \%$ of the 183 street children interviewed had been fostered (GoG/UNICEF, 2003).

The country witnessed an explosion of mostly unlicensed RCFs from the late 1990s, rising from 9 in 1998 to over 100 in 2005, taking care of almost 4500 children, of which $90 \%$ had one or both parents living (Csáky, 2009). The failure to regulate NGOs has resulted in a proliferation of RCFs (Laird, 2002). Galama (2010) and Voelkl (2012) have argued that whilst some RCFs are established with good intentions, the majority are used means to acquire funds from donors and orphanage tourism ${ }^{6}$. The unlicensed RCFs usually canvassed for children in the communities with the lure of providing them with education and health opportunities (Colburn 2010).

Formal foster care involving non relatives has been minimally used. By 2006, only 70 people were registered with the DSW as foster parents (Apt and Akuffo-Amoabeng, 2007). Part of the reason for the low patronage could be because carers were not paid for their services, making many people uninterested in becoming carers. In terms of adoption Ghana has not ratified the 1993 Hague Inter-country Adoption Convention even though some orphanages used it to engage in child trafficking (ACPF 2012). Domestic adoptions have remained unpopular due to the low level of information about adoption opportunities, the prohibitive cost for prospective parents and the rigid administrative procedures (Akpalu,

\footnotetext{
${ }^{4}$ Queen mothers are traditional leaders

5 In 1974 33\% of children who had one or both parents alive lived away from home compared with 14.3\% in 2008 (Source: Roby, 2011; GLSS, 2008).

${ }^{6}$ It is a form of tourism where individuals, generally from the advanced world, pay a fee to go and volunteer as caregivers in residential facilities in developing countries for a short period of time.
} 
2007).

\section{The Future of Child Welfare in Ghana}

In 2006, the focus of child welfare provision changed with the launch of the Care Reform Initiative, a component of the National Plan of Action for Orphaned and Vulnerable Children. The reform was initiated by three foreign organisations: UNICEF, USAID, and the U.S. based NGO OrphanAid Africa in partnership with DSW. The basis for the Care Reform Initiative was that studies undertaken in the developed world (notably Tolfree 1995; Bilson, 2009; Nelson et al., 2011 ) showed that long-term residential care can have detrimental effects on children's development and their human rights. The drastic increase RCFs in Ghana was therefore disturbing especially when allegations of sexual and physical abuse, corruption and human trafficking had emerged within several of these institutions (Adongo, 2011). These factors suggested a need for changes to ensure that child welfare provision in the country fell in line with the UN's 2009 guidelines on out-of-home care and the guidelines under the U.S. Assistance for Orphans and Other Vulnerable Children in Developing Countries Act 2005.

The aim of the Care Reform Initiative (CRI) consequently is to change policy and the provision of child welfare services. It is to enhance the capacity of the Department of Social Welfare in encouraging family and community based care as it is considered a more sustainable approach to child welfare. Residential care is to be avoided whenever possible and only be used as a last resort by shutting down $90 \%$ of the orphanages in the country (DSW, 2006).

The reform is to be undertaken through four components. The first and most important component is to strengthen the capacities of families through family support services in order to keep children within their original families and communities. This is largely in reaction to the observations in Ghana's state party report presented in 2006 to the UN's committee on the CRC. The committee's recommended in point 39 that the Ghana must take:

"necessary measures to support and strengthen the capacity of parents, particularly those in difficult circumstances, to perform their responsibilities in the upbringing of their children through family support programmes and facilitate the work of NGOs in this regard" (p.8).

The reform aims to identify and provide poor families with extra income through social grants and assistance programs so as to reduce the impact of poverty. Direct cash transfers through the Livelihood Empowerment against Poverty program (LEAP) is given to extremely poor caregivers of orphaned and vulnerable children to reduce the economic burden of care. Other social protection programmes like Education Capitation Grant (2005), School Feeding Programme (2004) and National Health Insurance (2003) aim to tackle child poverty by making education and health more accessible to poor families (Jones, Ahadzie and Doh, 2009). The social protection programs is also to keep parents alive (especially mothers) and support them to care of their children. The second component of the initiative is to reintegrate children separated from their families with extended family members who can provide them with a caring and stable environment. The remaining two components of the CRI aim to place children in foster care or give them up for adoption, most preferably in a Ghanaian family, if prevention and reintegration are not possible.

Since the implementation of the reforms, 15 orphanages have been closed down and 415 children living in RCFs reunited with their families (Adongo, 2011). Monthly stipends have been provided for 1,443 caregivers to care for 2,530 OVC in 21 districts where HIV prevalence is high. In terms of policy development which has occurred through the care reforms include the 2007 Foster Care Regulations and the 2010 Standards for Residential Homes. The foster and residential care regulations put in place statutory requirements for the preparation and aftercare support for care leavers. The new standards require that young people leaving foster or residential care be assisted and supported to acquire skills for productive living and eventual independence. In cases where the care leaver is not returning home to his or her family or an adoptive parent, the children's home and social welfare officer have to assist the young person to become independent and self-reliant and should keep regular contact with him or her for a period between one to six years.

The CRI has, however, experienced some challenges with the most prominent of them being lack of resources. The DSW does not have the personnel, logistics and funds to carry out its mandate under the reforms (Bortey-Doku Aryeetey et al., 2012). Some of the regulations under the refom are highly unattainable, at least for now, given Ghana's social work and social welfare provision. For instance, the standards require that young people leaving residential or foster care should be supported by personal social worker for a period of one to six years. However, given that Ghana has just over 800 social workers for the entire country, the prospect of care leavers being supported by aftercare social workers seems very unlikely.

In addition there is an absence of a clearly-defined child policy framework (Baffoe \& Dako-Gyeke, 2013). The care 
reform was not accompanied by detailed guidelines or procedures and has only been guided by issue-specific plans. There is no sector wide approach to the provision for children under the reform. As a result while organisations like the Domestic Violence Victim Support Unit (DOVVSU) working with abused children are establishing of shelters for children, the DSW's is pursuing a deinstitutionalization strategy for orphans and abandoned children (Casey, 2011).

Findings from research studies seem to undermine some of the core reasons underpinning the care reform. One of the main goals of the reform initiative is deinstitutionalisation by closing down about $90 \%$ privately unregistered residential care institutions. However, the findings from the two studies (Colburn, 2010; Kristiansen, 2009) that many well-run private homes provide good standards of living and care for children. Gyapong et al. (2011) also found that children in orphanages had better education, nutrition and health services than orphans who were in their households within the community. Lemons (2010) argues even though enforcing international standards is laudable, there should not be a rush to close down functional orphanages just because Ghana's wants to receive international aid. The author suggests that the standards set by the reform should rather be based on Ghana's own standards which take into consideration Ghana's infrastructure and resources.

Lastly, Maclean (2011: 133) believes that because no reliable data exist in Ghana on the extent and operation of the informal institutions of reciprocity "many donors and policymakers maintain an overly romanticized image of kinship and communal reciprocity in Africa. When policies are designed based on these assumptions, it is the very poor that increasingly fall through the gaps of the state and non-state system of social welfare". Voyk (2010) is of the view that the reform's attempt to shift the care of dependent children from residential care to family and community based care would only succeed if ways are found to fix the social problems like harmful practices, provide HIVIAIDS awareness and education to lessen stigma and enhance income-generating capacities of poor families before reintegrating children. Without this the author believes that children that are being moved from institutionalised care back into the community would likely to face more hardships than remaining under orphanage care.

\section{Conclusion}

The family in its extended form have, and still are, providing the majority of alternative parental care for children who need it. However, over the years the traditional system's capacity to provide this care has been gradually weakened by factors including poverty and HIV. In response the missionaries and then the colonial government introduced residential care to take care of children who could not be cared for within their families. After independence residential care was adopted as the main out-of-home care which resulted in a proliferation especially in the late 1990s. With a return to democracy in the 1990s, the country developed a good array of child protection laws this made little impact on the lives of children due to weak implementation and enforcement. Ghana still lacks a national In the last few years Ghana has begun a reform of its child welfare system by shifting from residential care facilities to family and community based care alternatives for dependent children. The reform is based on a dynamic partnership between the formal systems and the existing community structures and traditions. Though Ghana's quest to deinstitutionalise continues to be a possibility and something good for the future, there are some things that have to be put in place before it becomes a reality. In the meantime, however, there is a need to consider some of the ways in which institutions need to be developed for better conditions for children.

\section{References}

Adongo, S.T. (2011) 'Realising the Rights of Children in Ghana: Towards Homes without Walls, Paper presented at the Way Forward Project Second Working Groups Convening, Addis Ababa, Ethiopia, 24-27 May.

Adésínà J.O. (2009) 'Social Policy in sub-Saharan Africa: A Glance in the Rear-View Mirror. International Journal of Social Welfare':S37-S51.

Agyeman-Duah, I. (ed) (2008) An Economic History of Ghana: Reflections on a Half-Century Of Challenges and Progress. Banbury: Ayebia Clarke.

Akpalu, D.A. (2007) 'Adoption of Children and the Contribution of Osu Children's Home in Ghana', Children and Youth Services Review 29: 1070-1084.

Allman, J. (1997) 'Fathering, Mothering and Making Sense of Ntamoba: Reflections on the Economy of Child-rearing in Colonial Asante', Africa 67 (2): 296-322.

Ampofo Adomako, A., Alhassan, O., Ankrah, F., Atobrah, D. and Dortey, M. (2007) Examining the sexual exploitation children on the streets of Accra. Accra: UNICEF.

Ansah-Koi, A.A. (2006) 'Care of Orphans: Fostering Interventions for Children whose Parents die of AIDS in Ghana', Families in Society: The Journal of Contemporary Social Services 87(4): 555-64. 
Anson-Yevu VC (1988) A case study on special education in Ghana. Accra: UNESCO.

Apt, N.A. (1974) 'Children without Parents: A Ghanaian Case Study', Legon Family Research Papers 4: 80-84.

Apt, N.A. and Blavo, E.Q. (1997) 'Ghana', in N.S. Mayadas, D, Elliott and T.D. Watts (eds) International handbook on social work theory and practice. London: Greenwood Press.

Apt, N.A., Blavo, E. and Wilson, S. (1998) Children in need: A study of children in institutional homes in Ghana. Report, University of Ghana, Ghana, March.

Apt, N.A. (2005) A Study of Child Domestic Work and Fosterage in Northern and Upper East Regions of Ghana. Accra: UNICEF.

Apt, N. A. and Akuffo-Amoabeng, B. (2007) Department of Social Welfare Institutional Assessment. Accra: Ministry of Manpower, Youth and Employment.

Apusigah, A. (2007) Child Protection Project in Northern and Upper East Regions: Assessment. DSW, Department of Community Development and UNICEF.

Aryeetey, E. and Goldstein, M. (2000) 'Ghana social reform in Africa', in G. Morales., N. Tschirgi., and J.L. Moher., (eds) Reforming social policy: Changing perspectives on sustainable human development, pp. 9-43. Dakar: International Development Research Centre.

Aryeetey Bortei-Doku, E., Afranie, S., Andoh, P., Doh, D. and Antwi-Bosiakoh, T. (2012) Where Do We Stay? Exploring the Options of Caring for Orphans and Vulnerable Children in Ghana. Report, University of Ghana, January.

Asamoah, Y.W. and Nortey, D.N.A. (1987) 'Ghana' in J. Dixon (ed) Social welfare in Africa. Beckenham: Croom Helm Ltd.

Asamoah, Y.W. (1997) 'Africa', in T.D. Watts, D. Elliott and N.S. Mayadas (eds) International handbook on social work education. Westport, CT: Greenwood Press.

Asrifi, Y. (2009) 'Child Health: Past, Present and Future Challenges', Ghana Medical Journal 43(2): 82-85.

Atobrah, D. (2004) 'Children of Dead Mothers and Unknown Fathers', Research Review Supplement 16: 59-76.

Bukh, J. (1979) The Village Woman in Ghana. Uppsala: Scandinavian Institute of African Studies.

Casey, S. (2011) Report of the Mapping and Analysis of Ghana's Child Protection System. Accra: Department of Social Welfare and UNICEF.

Colburn, J. (2010). Orphanages of Accra: A Comparative Case Study on Orphan Care and Social Work Practices, at: http://digitalcollections .sit.edu/isp_collection/850 (accessed October 2012).

Craven, C.M. (1935) 'Juvenile Delinquency in the Colonies', The Howard Journal of Criminal Justice 4(2): 179-185.

Crentsil, P. (2009) 'Caring for AIDS Orphans in Ghana'. Suomen Antropologi 34 (3): 82-83.

Csáky, C. (2009) Keeping Children out of Harmful Institutions: Why we Should Be linvesting in Family-Based Care. London: Save the Children Fund.

Department of Social Welfare and Community Development (1955) Problem Children of the Gold Coast. Accra: Government Printer.

Dozier, M., Zeanah, C.H., Wallin, A.R., \& Shauffer, C. (2012) 'Institutional Care for Young Children: Review of Literature and Policy Implications', Social Issues and Policy Review 6(1): 1-25.

Fiawoo, D.K. (1959) 'Urbanisation and Religion in Eastern Ghana', The Sociological Review 7(1): 83-97.

Galama, A. (2010) The NGOs are breaking down our system: Vulnerable children, NGOs, and the proliferation of orphanages in Ghana. Master's Thesis, Radboud Universiteit Nijmegen, Netherlands.

Ghana Statistical Service (2008) Ghana living standards survey: Report of the fifth round. Accra: Ghana Statistical Service.

GoG/UNICEF (2003) Rights Promotion and Protection Interventions: Protecting Street Girls and Child Migration. Accra: Midterm Evaluation of the Rights and Child Protection Components of Government of Ghana-UNICEF Country Programme.

Goody, E. (1966) 'The Fostering of Children in Ghana: A Preliminary Report', Ghana Journal of Sociology 2(1): 26-33.

Goody, E. (1973) Context of kinship: Essay in the family sociology of Gonja of Northern Ghana. Cambridge: Cambridge University Press.

Government of Ghana (2007). Standards for the Operation of Residential Care Settings in Ghana. Accra: Assembly Press.

Gyeke, K. (1996) African Cultural Values: An Introduction. Accra: Sankofa Publishing Company.

Hill, A. (1962) 'Administrative Structure for Social Welfare in West Africa', in C. Drake and T.P. Omari (eds) Social work in West Africa (Report of The Seminar on Social Work in West Africa). Accra: Ghana Publishing.

Imoh Twum-Danso, I. (2012) 'From Central to Marginal? Changing Perceptions of Kinship Fosterage in Ghana', Journal of Family History 37(4): 351-363.

Jones N, Ahadzie, W. \& Doh, D. (2009) Social Protection to Tackle Child Poverty in Ghana. London: Overseas Development Institute.

Jones, N., Ahadzie, W., \& Doh, D. (2009) Social Protection and Children: Opportunities and Challenges in Ghana. Accra: UNICEF and Ministry of Employment and Social Welfare.

Kaye, B. (1962) Bringing up Children in Ghana: An Impressionistic Survey. London: George Allen and Unwin Ltd.

Khemchyan, H., Robinson, T. and Quashigah, K. (2008) Legislative Reform Related to the Convention on the Rights of the Child in Diverse Legal Systems. New York: UNICEF.

Konings, P. (2002) 'Structural Adjustment and Trade Unions in Africa: The Case of Ghana', in A. E. Fernadez and M. Riethof (eds) Labour Relations in Development. London: Routledge.

Kristiansen, M. (2009) The Quality of Life of Children Living in Residential Child Care Facilities: A Comparative Study of Three Children's Homes in Accra and Cape Coast, Ghana. Master's Thesis, Norwegian University of Science and Technology, Norway.

Kuyini, A.B., Alhassan, A.R., Tollerund, I., Weld, H. and Haruna, I. (2009a) 'Traditional Kinship Foster Care in Northern Ghana: The Experiences and Views of Children, Carers, and Adults in Tamale', Child and Family Social Work 14(4): 440-449. 
Laird, S.E. (2002) 'The 1998 Children's Act: Problems of Enforcement in Ghana', British Journal of Social Work 32(7): 893-905.

Laird, S.E. (2011) 'Enforcing the Law on Child Maintenance in sub-Saharan Africa: A Case Study of Ghana', International Journal of Law, Policy and the Family 25(2): 220-243.

Lemons, Elizabeth. (2010) The Experience of the AIDS Orphan in the Central and Eastern Regions of Ghana: Communication between Caregivers and Orphans Regarding HIVIAIDS. Senior Honors Thesis, The Ohio State University, US.

Little, K. (1960) 'Western African Urbanisation as a Social Process', Journal of African Studies: 90-102.

Lord, J. (2011) 'Child Labour in the Gold Coast: The Economics of Work, Education and the Family in Late Colonial Africa', The Journal of the History of Childhood and Youth 4(1): 88-115.

Lund, R. and Agyei-Mensah. S. (2008) 'Queens as Mothers: The Role of the Traditional Safety Net of Care and Support for HIVIAIDS Orphans and Vulnerable Children in Ghana', GeoJournal 71(2-3): 93-106.

Maclean, L. M. (2011) 'Exhaustion and Exclusion in the African Village: The Non-State Social Welfare of Informal Reciprocity in Rural Ghana and Cote d'Ivoire', Studies in Comparative International Development 46(1): 118-136.

Manful, E. and McCystral, P. (2011) 'Ghana's Children's Act 560: A Rethink of its Implementation', International Journal of Children's Rights 19(2): 151-165.

Manful, S.E. and Badu-Nyarko, S.K. (2011) 'Where are the HIVIAIDS Orphans? Exploring Characteristics of Vulnerable Children in Public Residential Care in Ghana?', Journal of Global Social Work Practice 4(1): 1-8.

Mends, E. H. (1994) 'The Rights of the Child in Ghana: The Socio-Cultural Milieu', in H. J. A. N. Mensa-Bonsu, \& C. DowuonaHammond (eds) The Rights of the Child in Ghana-Perspectives. Accra: Woeli Publishing Services.

Murove, T., Forbes, B., Kean, S., Wamimbi, R. and Germann, S. (2010) 'A Discussion of Perceptions of Community Facilitators from Swaziland, Kenya, Mozambique and Ghana: Cultural Practices and Child Protection', Vulnerable Children and Youth Studies: An International Interdisciplinary Journal for Research, Policy and Care 5(S1): 55-62.

Nukunya, G.K. (2003) Tradition and Change in Ghana: An Introduction to Sociology, 2nd edn. Accra: Ghana University Press.

Oppong, C. (1973) Growing Up in Dagbon. Tema: Ghana Publishing Corporation.

Payne, C.J. and White, K.J. (1979) Caring for Deprived Children. London: Croom Helm Limited.

Schildkrout, E. (1973) 'The Fostering of Children in Urban Ghana', Urban Anthropology 2: 48-73.

Sossou, M.A. and Yogtiba, J.A. (2009) 'Abuse of Children in West Africa: Implications for Social Work Education and Practice', British Journal of Social Work 39(7): 1218-1234.

Tetteh, P. (2011) 'Child Domestic Labour in (Accra) Ghana: A Child and Gender Rights Issue?', International Journal of Children's Rights 19: 217-232.

UN (2009) Child adoption: Trends and policies. New York: United Nations Publications.

UNICEF (2009) Children in Ghana. Accra: Ministry of Women and Children Affairs.

Van der Geest, S. (2004) 'Orphans in Highlife: An Anthropological Interpretation', History of Africa 31: 425-440.

Voelkl, H.T. (2012) The Experience of Children with International Volunteer Tourists: A Case Study in an Orphanage in Ghana. Masters Thesis, Brunel University, UK.

Voyk, E. (2011) Orphan Vulnerability, NGOs and HIVIAIDS in Ghana. Master's Thesis, Ohio State University, USA.

Windborne, J. (2006) 'New Laws, Old Values: Indigenous Resistance to Children's Rights in Ghana', Atlantic Journal of Communication 14(3): 156-172. 